\title{
Use of Prochilodus lineatus meat for burger making
}

\author{
Aproveitamento da carne de Prochilodus lineatus para \\ elaboração de hambúrguer
}

\begin{abstract}
Alexandra Pretto ${ }^{1 *}$ (1), Antonio Cleber da Silva Camargo ${ }^{1}$, Cristiano Miguel Stefanello', Caroline Naomi Kuroda ${ }^{1}$, Guilherme Masteloto da Rosa ${ }^{1}$, Gabriel de Paula Gollino², Vanessa Bley Ribeiro ${ }^{3}$, Alessandra Sayuri Kikuchi Tamajusuku Neis ${ }^{1}$
\end{abstract}

${ }^{1}$ Universidade Federal do Pampa (UNIPAMPA), Curso de Tecnologia em Aquicultura, Uruguaiana/RS - Brasil ${ }^{2}$ Universidade Federal do Pampa (UNIPAMPA), Programa de Pós-graduação em Farmácia, Uruguaiana/RS - Brasil

${ }^{3}$ Universidade Federal do Pampa (UNIPAMPA), Curso de Farmácia, Uruguaiana/RS - Brasil

*Corresponding Author: Alexandra Pretto, Universidade Federal do Pampa (UNIPAMPA), Curso de Tecnologia em Aquicultura, BR 472, km 585, CEP: 97501-970, Uruguaiana/RS - Brasil,

e-mail: alexandrapretto@unipampa.edu.br

Cite as: Pretto, A., Camargo, A. C. S., Stefanello, C. M., Kuroda, C. N., Rosa, G. M., Gollino, G. P., Ribeiro, V. B., \& Neis, A. S. K. T. (2020). Use of Prochilodus lineatus meat for burger making. Brazilian Journal of Food Technology, 23, e2019230. https://doi.org/10.1590/1981-6723.23019

\begin{abstract}
The study aimed to elaborate burgers with fillet and pulp (fish carcass meat) of grumatã (Prochilodus lineatus), and to evaluate its centesimal composition, microbiological and sensorial properties. Three formulations were prepared. One was prepared with the fillet ( $0 \%$ pulp), and the remaining two contained $15 \%$ or $30 \%$ pulp (instead of fillet), textured soy protein, wheat flour and condiments. The centesimal and microbiological composition was evaluated in pre-ready burgers. For sensory analysis, the burgers were grilled, and untrained judges evaluated the appearance, color, taste, texture, overall acceptance and purchase intent. Dry matter and fat were higher in formulations containing pulp; while crude protein and ash contents were higher in burgers with $30 \%$ pulp compared with those produced with fillet only. The coagulase-positive Staphylococcus and total and fecal coliform counts were within normal values established by the Brazilian legislation. Salmonella spp. was detected in the pre-ready (raw) formulations, but no colony was observed in the cooked preparations. Although no difference was found among formulations for sensory attributes, burgers with $30 \%$ pulp presented a higher purchase intention index (50\%) than the other formulations. The complete use (fillet and pulp) of grumatã meat shows that this species can be utilized to elaborate distinct alimentary formulations.
\end{abstract}

Keywords: Grumatã; Integral use of meat; Fish pulp; Food formulation; Value-added product; Sensory evaluation; Centesimal composition.

\section{Resumo}

O estudo visou elaborar hambúrgueres com filé e polpa (carne da carcaça do peixe) de grumatã (Prochilodus lineatus) e avaliar sua composição centesimal, microbiológica e sensorial. Foram feitas três formulações. Uma foi preparada com o filé ( $0 \%$ polpa) e as duas restantes continham $15 \%$ ou $30 \%$ de polpa em substituição ao filé, além de proteína texturizada de soja, farinha de trigo e condimentos. A composição centesimal e microbiológica foi 
avaliada nos hambúrgueres pré-prontos. Para análise sensorial, os hambúrgueres foram grelhados e julgadores não treinados avaliaram a aparência, cor, sabor, textura, aceitação global e intenção de compra. Matéria seca e gordura foram superiores nas formulações contendo polpa e o conteúdo de proteína bruta e cinzas foram superiores nos hambúrgueres com $30 \%$ polpa em relação àqueles produzidos somente com filé. A contagem de estafilococos coagulase positiva e coliformes totais e fecais mostrou-se dentro dos valores estabelecidos pela legislação brasileira. A presença de Salmonella spp. foi detectada nas formulações pré-prontas (cruas), mas nenhuma colônia foi observada nas preparações grelhadas. Apesar de nenhuma diferença ter sido encontrada entre as formulações para os atributos sensoriais, os hambúrgueres com 30\% polpa apresentaram maior índice de intenção de compra (50\%) em relação às demais formulações. O aproveitamento completo (filé e polpa) da carne de grumatã mostra que esta espécie é adequada para elaborar distintas formulações alimentícias.

Palavras-chave: Grumatã; Aproveitamento integral de carne; Polpa de pescado; Formulação alimentícia; Valor agregado de produtos; Avaliação sensorial; Composição centesimal.

\section{Introduction}

The genus Prochilodus represents a wide distribution and biomass in some rivers in Brazil, so the specimens of this genus have great importance for the country's commercial fishing (Fonseca et al., 2010). The curimbatá or grumatã, as this species is popularly known, is among the most hand-caught species in Brazil (28,432 $t$ in 2010), according to data from the Ministry of Fisheries and Aquaculture (Brasil, 2012). Species of this genus also have the potential for commercial breeding, regarding rusticity, consolidated breeding and breeding techniques, and ease of handling (Moro et al., 2013). However, the presence of intramuscular spines, the odor and the taste of earth and mold of the meat (off-flavor), are obstacles for the industrial processing and commercialization of these species (Reidel et al., 2004).

One of the alternatives to reduce or even eliminate the off-flavor is the depuration process, because fasting and continuous circulation of good quality water facilitate the loss of undesirable meat odors/flavors (Maciel et al., 2012). Another commercialization approach for species like grumatã is to process all the meat of the fish, either manually or with specific machines, for use in food formulations, rather than commercializing the whole fish or only the fillet (Reidel et al., 2004; Bombardelli et al., 2005). The grumatã yields up to $50 \%$ of body weight in meat, much higher than other fishes (tilapia $31 \%$ on average, pacu from $28 \%$ to $32 \%$ ) (Pinheiro et al., 2006; Basso et al., 2011), showing the great potential of this species for the fish processing industry. In addition, full utilization of meat (fillet and mechanically-separated meat or pulp) results in economic, social and environmental benefits in the fish chain (Pires et al., 2014). Targeting fish meat, such as grumatã, for the preparation of high-nutritional-value food formulations can diversify the supply of fish products available for the consumer at an affordable price, as well as can contribute to increase fish consumption.

In the context of optimizing the use and consumer acceptance of the grumatã meat, this study elaborated formulations of burgers with grumatã fillet and pulp, in different proportions, and evaluated their centesimal composition, and microbiological and sensorial properties.

\section{Material and methods}

The study was registered in the System of Authorization and Information of Biodiversity (SISBIO) under number 47353/3. All procedures involving food handling and sensory analysis were approved by the Research Ethics Committee of the Federal University of Pampa (39982314.0.0000.5323). 


\subsection{Fish collection and depuration process}

The specimens of grumatã (Prochilodus lineatus) were collected with 7-cm mesh nets in the dam (Uruguaiana, RS, Brazil), during the spring of 2018. The collected females had an average weight of $2.5 \mathrm{~kg}$, and the males of $1.6 \mathrm{~kg}$. The fish were brought in a live fish transport box $(250 \mathrm{~L})$ to the Fisheries and Aquaculture Technology Centre of the Federal University of Pampa, Uruguaiana Campus (Brazil), and distributed into three tanks ( 8 fish/tank) with an average of $2100 \mathrm{~L}$ per tank and continuous flow of water $(7.06 \pm 1.38 \mathrm{~L}$ on average). In addition to the flow rate, the temperature and oxygen of the tanks' water were monitored daily using a digital oximeter (Politerm - POL 60, SP, Brazil). The mean water temperature remained at $22.85 \pm 0.52{ }^{\circ} \mathrm{C}$ and oxygen at $4.00 \pm 1.24 \mathrm{mg} / \mathrm{L}$. Before being distributed in the tanks, the fish were weighed (electronic scale, BEL Engineering, M5202, SP, Brazil) and measured (digital caliper, Starret 797 Series, SP, Brazil) to verify the weight loss after $96 \mathrm{~h}$ of depuration, the period established in a previous study (Pretto et al., 2017). The mean stocking density in each tank was $8 \mathrm{~g} / \mathrm{L}$.

\subsection{Fish slaughtering and filleting}

After depuration, the fish were slaughtered by hypothermia (water:ice 1:1), and again weighed and measured. The weight loss (\%) was calculated by the difference between the initial weight and the weight after depuration. Then, each fish was filleted, and the fillet was weighed to calculate the yield (\%) (fillet weight $\times 100 /$ total fish weight). The fillet and carcass (filleted body, viscera and head) were washed in tap water and then in water containing $10 \mathrm{ppm}$ chlorine, packed and stored at $-18{ }^{\circ} \mathrm{C}$. At a later stage, the carcasses were cooked in an electric oven $\left(250^{\circ} \mathrm{C}\right.$ for $\left.15 \mathrm{~min}\right)$ to remove the remaining meat, which was called pulp. The average yield of pulp (\%) was calculated relative to the weight of the whole fish.

\subsection{Preparation of burger formulations}

The fillet was ground using a meat grinder (Braesi, BMC-05, $4 \mathrm{~mm}$ aperture, RS, Brazil) prior to the production of the burgers. The burgers were formulated based on the studies of Bernardino Filho et al. (2014) and Munhoz \& Camponazo (2018), with modifications implemented from preliminary tests. The treatments corresponded to different levels of inclusion of grumatã pulp (15\% or 30\%), beyond the formulation without pulp inclusion ( $0 \%$ or control), and are presented in Table 1 .

Table 1. Burger formulations based on fillet and grumatã pulp.

\begin{tabular}{cccc}
\hline \multirow{2}{*}{ Ingredients (\%) } & \multicolumn{3}{c}{ Formulations } \\
\cline { 2 - 4 } & $\mathbf{0 \%}$ pulp & $\mathbf{1 5 \%}$ pulp & $\mathbf{3 0 \%}$ pulp \\
\hline Meat of grumatã (fillet) & 83.70 & 71.14 & 58.59 \\
\hline Meat of grumatã (pulp) & - & 12.55 & 25.11 \\
\hline Texturized soy protein & 4 & 4 & 4 \\
\hline Wheat flour & 5 & 5 & 5 \\
\hline Spice & 4.5 & 4.5 & 4.5 \\
\hline Black pepper & 0.5 & 0.5 & 0.5 \\
\hline Garlic paste & 1.0 & 1.0 & 1.0 \\
\hline Salt & 1.3 & 1.3 & 1.3 \\
\hline
\end{tabular}

${ }^{a}$ Dehydrated condiment based on onion, garlic, parsley, oregano, basil, bay leaf, black pepper, ground red pepper, mustard, pepper (known as chimichurri).

Fat was not included in the burgers formulation because the meat of grumatã is high in fat. The soy textured protein was weighed and then hydrated in water $(1: 2, \mathrm{w} / \mathrm{v})$ before use. All the ingredients (fillet, pulp, textured soy protein, wheat flour, spice, black pepper, garlic paste, salt) were weighed and mixed manually until a homogeneous mass was obtained. Next, $100 \mathrm{~g}$ portions were separated, and the burgers pressed into a burger 
mold ( $14 \mathrm{~cm}$ in diameter), wrapped in plastic wrap and stored at $-18{ }^{\circ} \mathrm{C}$ until the centesimal, microbiological and sensorial analyses.

\subsection{Laboratory analyses}

The centesimal composition of the fillet, pulp and pre-cooked burgers (before grilling) was analyzed for dry matter (oven at $105^{\circ} \mathrm{C}$ for $24 \mathrm{~h}$ ), mineral matter (muffle incineration at $500{ }^{\circ} \mathrm{C}$ for $4 \mathrm{~h}$ ) and crude protein $(\mathrm{N} \times 6.25$ by the micro-Kjeldahl method), according to the procedures proposed by the Association of Official Analytical Chemists (1995). Fat was extracted and quantified by the cold extraction method proposed by Bligh \& Dyer (1959). The analyses were performed in quadruplicate on samples randomly extracted from each treatment.

In order to investigate the microbiological characteristics of the pre-cooked burgers, total and fecal coliform counts were determined by the most probable number (MPN) technique, coagulase positive Staphylococcus count on mannitol agar and Salmonella spp. on XLD agar. We used the methods proposed by the Ministry of Agriculture, Livestock and Supply (Brasil, 2003). These analyses were performed on a sample of each treatment.

For the sensory analysis, the burgers were thawed and grilled on both sides until apparent cooking (6 to 7 min reaching an internal temperature of around $80{ }^{\circ} \mathrm{C}$ ). At the Institution's Animal Products Technology Laboratory (Federal University of Pampa, Uruguaiana Campus, Brazil), 54 untrained judges (randomly selected people from the academic community) evaluated the burgers prepared with the different formulations. Before starting the evaluation, the judges were advised about the evaluation method and procedure, and signed the Informed Consent Form. Samples of burgers were provided on a platter, identified by numerical codes to avoid possible information of the burgers under analysis. The judges also received water at room temperature and saltine crackers to clear the palate when tasting the burgers of each treatment. The acceptance test of the product evaluated the attributes of appearance, color, texture, taste, global acceptance on a 9-point hedonic scale $(1=$ very disagreeable and $9=\mathrm{I}$ liked very much $)$ as proposed by Dutcosky (2011). The judges also responded to the burgers' purchase intent test.

\subsection{Statistical analysis}

The centesimal composition and sensory analysis data were evaluated by analysis of variance, and the means were compared by Tukey's test $(p<0.05)$, using the statistical program SPSS 21.0.

\section{Results and discussion}

\subsection{Meat yields after depuration process}

After depuration for $96 \mathrm{~h}$, the mean weight loss of females and males of grumatã was $6.5 \%$. The fillet yield was $31.33 \% \pm 5.29 \%$, and the pulp yield was $11.05 \% \pm 4.12 \%$. Thus, the total yield of grumatã meat reached more than $42 \%$ of its live weight. In a previous study (Pretto et al., 2019), this yield reached $50.79 \%$. Aspects that may alter fish meat yields are size or age, breeding season and skill of the filleting operator (Gomiero et al., 2003). These data reveal the great potential of meat production of grumatã, a species that can be widely exploited in the production of food formulations of high nutritional value, but which is underutilized because of the taste and odor of the meat of the wild specimens when commercialized. 


\subsection{Laboratory analysis}

\subsubsection{Centesimal composition}

Regarding the centesimal composition, in the fillet of grumatã, values of $34.16 \% \pm 0.58 \%$ dry matter, $1.08 \% \pm 0.05 \%$ ash, $18.19 \% \pm 0.26 \%$ crude protein and $9.77 \% \pm 0.50 \%$ fat were found. In another study, values of $33.5 \%$ dry matter, $1.4 \%$ ash, $14.6 \%$ crude protein and $9.9 \%$ fat were observed in the grumatã fillet (Pretto et al., 2019). The centesimal composition values of grumatã fillet in the present study are also similar to the results found by Machado \& Foresti (2009), but with a much higher fat content in fish caught in the dam (present study) than in those caught in the river. For the pulp, values of $36.18 \% \pm 0.55 \%$ dry matter, $1.04 \% \pm 0.09 \%$ ash, $22.64 \% \pm 0.91 \%$ crude protein and $13.52 \% \pm 0.99 \%$ fat were found. The highest percentage of dry matter and protein of the pulp results from the loss of water in the cooking process to remove the residual meat from the carcass. The largest percentage of fat in the raw material relative to the fillet is because the remaining meat is derived from body parts with greater accumulation of fat, such as the ventral region of the body and near the viscera, compared with the lower fat deposition in the dorso-lateral region of the body, from where the fillet (epaxial and ipaxial muscles) is removed (Oliveira et al., 2014). The mechanically-separated meat of Nile tilapia (Oreochromis niloticus) presents comparatively more moisture $(20.95 \%$ dry matter), and lower concentrations of protein and ash $(14.63 \%$ crude protein, $0.87 \%$ ash) because the pulp is obtained from raw material, unlike the present study in which the pulp was obtained after cooking. However, tilapia meat presents relatively low fat content (Bordignon et al., 2010).

The centesimal composition data of the formulations containing fillet and a mix of fillet and pulp of the grumatã are shown in Table 2. The formulation produced without the inclusion of grumatã pulp (i.e., with the fillet only) had a lower percentage of dry matter and lower contents of ash, crude protein and fat compared with the formulation with a higher percentage of pulp. The inclusion of pulp in the formulations resulted in a higher content of ash, protein and fat, which is due to the characteristics of this raw material.

Table 2. Centesimal composition of burgers containing fillet and grumatã pulp.

\begin{tabular}{ccccc}
\hline \multirow{2}{*}{ Formulations } & \multicolumn{3}{c}{ Variable (\%) } \\
\cline { 2 - 5 } & Dry matter & Ash & Crude protein & Fat \\
\hline $0 \%$ pulp & $38.13 \pm 0.09^{\mathrm{c}}$ & $2.18 \pm 0.09^{\mathrm{b}}$ & $17.59 \pm 0.39^{\mathrm{b}}$ & $6.90 \pm 0.44^{\mathrm{b}}$ \\
\hline $15 \%$ pulp & $40.74 \pm 0.59^{\mathrm{a}}$ & $2.38 \pm 0.09^{\mathrm{ab}}$ & $18.38 \pm 0.55^{\mathrm{ab}}$ & $8.55 \pm 0.35^{\mathrm{a}}$ \\
\hline $30 \%$ pulp & $39.47 \pm 0.26^{\mathrm{b}}$ & $2.46 \pm 0.09^{\mathrm{a}}$ & $19.01 \pm 0.74^{\mathrm{a}}$ & $8.13 \pm 1.09^{\mathrm{a}}$ \\
\hline
\end{tabular}

Results expressed as mean \pm standard deviation $(n=4)$. Letters indicate statistical difference between formulations by Tukey’s test $(p<0.05)$.

Bochi et al. (2008) observed that the inclusion of pulp from filleting residues of silver catfish (Rhamdia quelen) also resulted in formulations with higher fat content, but only when $80 \%$ of pulp replaced the fillet. According to the Brazilian legislation, the burgers must present among other characteristics, a maximum of $23 \%$ fat and at least $15 \%$ crude protein, and the inclusion of non-meat protein as soy protein is limited to $4 \%$ of the formulation (Brasil, 2000). Therefore, our formulations are in agreement with the technical regulations. However, moisture, crude protein and fat contents vary greatly based on the centesimal composition of the fish species used in the formulation. For example, the preparation of burgers using Pterodoras granulosus or Pimelodus britskii meat resulted in formulations containing values of fat close to $12 \%$ (Finkler et al., 2010; Munhoz \& Camponazo, 2018), while using Cichla ssp. meat (tucunaré), the fat value was $0.38 \%$ (Bernardino Filho et al., 2014). However, an important aspect is that the inclusion of grumatã pulp in the burger formulations eliminates the need to include any other source of fat, besides the supply of excellent quality fatty acids. 


\subsubsection{Microbiological analysis}

The results of the microbiological analysis (Table 3) showed that the pre-ready burger formulations comply with the current legislation regarding coagulase-positive Staphylococcus counts and total and fecal coliforms. However, Salmonella spp. was detected in these formulations, yet the legislation advocates the total absence of this bacterial genus in any food preparation (RDC $\mathrm{N}^{\circ} 12$, de 2001, National Health Surveillance Agency) (Brasil, 2001).

Table 3. Microbiological analysis of pre-ready burgers.

\begin{tabular}{ccccc}
\hline Parameter & \multicolumn{3}{c}{ Formulations } & $\begin{array}{c}\text { Limit according to } \\
\text { Brazilian legislation } \\
\text { (RDC N 12, 2001)* }\end{array}$ \\
\cline { 2 - 5 } & $\mathbf{0 \%}$ pulp & $\mathbf{1 5 \% \text { pulp }}$ & $\mathbf{3 0 \% \text { pulp }}$ & 1000 \\
\hline $\begin{array}{c}\text { Coagulase-positive } \\
\text { Staphylococcus (CFU/g) }\end{array}$ & 20 & 85 & 160 & 1000 \\
\hline Total coliforms (MPN/g) & 93 & 15 & 11 & Absent \\
\hline Fecal coliforms (MPN/g) & 21 & 43 & Positive & Absent \\
\hline $\begin{array}{c}\text { Salmonella } \text { spp. } \\
\text { (in 25 g raw sample) }\end{array}$ & Positive & Positive & Negative & Negative \\
\hline $\begin{array}{c}\text { Salmonella } \text { spp. } \\
\text { (in 25 g cooked sample) }\end{array}$ & Negative & .
\end{tabular}

*Resolution RDC No 12, 2 January 2001, of the National Sanitary Surveillance Agency (Brasil, 2001).

In order to evaluate the safety of the formulations, samples of each treatment were grilled and re-tested, resulting in no growth of Salmonella spp. This result shows the efficiency of the cooking process (temperature around $80^{\circ} \mathrm{C}$ inside the food), which is capable of eliminating potentially pathogenic microorganisms and minimizing the risks for consumers' health. The bacterium Salmonella spp. is not a component of the fish natural microbiota, instead it is introduced through contaminated water or improper handling throughout fish processing. In fish, its pathogenesis is unknown, and there are no reports of infections. However, it may remain in the gastrointestinal tract, skin, gills and muscle, which could facilitate the occurrence of cross-contamination during the stages of slaughter and processing (Fernandes et al., 2018). In this context, the hygiene during all the stages of processing must be carefully monitored so that no contamination occurs.

\subsubsection{Sensory analysis and purchase intention}

The sensory analysis of the burgers showed no difference in the attributes of appearance, color, texture, flavor and overall acceptance between the formulations containing pulp compared with the formulation produced only with the fillet of grumatã (Table 4). All formulations had a mean score between 7 (moderately enjoyed) and 8 (I enjoyed it a lot).

Table 4. Acceptance test of burgers containing fillet and grumatã pulp.

\begin{tabular}{|c|c|c|c|c|c|}
\hline \multirow[b]{2}{*}{ Formulation } & \multicolumn{5}{|c|}{ Parameters } \\
\hline & Appearance & Color & Texture & Flavor & $\begin{array}{c}\text { Overall } \\
\text { acceptance }\end{array}$ \\
\hline $0 \%$ pulp & $7.30 \pm 1.23$ & $7.28 \pm 1.34$ & $7.46 \pm 1.36$ & $7.32 \pm 1.52$ & $7.42 \pm 1.23$ \\
\hline $15 \%$ pulp & $7.49 \pm 1.32$ & $7.47 \pm 1.28$ & $7.70 \pm 1.08$ & $7.60 \pm 0.99$ & $7.60 \pm 0.91$ \\
\hline $30 \%$ pulp & $7.42 \pm 1.43$ & $7.52 \pm 1.42$ & $7.76 \pm 1.17$ & $7.44 \pm 1.76$ & $7.58 \pm 1.60$ \\
\hline
\end{tabular}

Results expressed as mean \pm standard deviation $(n=54)$.

Mello et al. (2012) concluded that the sensory acceptance (flavor, texture, overall acceptance) of burgers made from Nile tilapia fillet waste pulp was superior to the formulations produced with surimi from the same raw material. The same study also revealed that the formulation with pulp had a $50 \%$ lower cost compared with the use of surimi. This result indicates that the use of fish pulp, besides optimizing the use of the meat 
remaining in the fish carcass and producing formulations of high acceptance by the consumer, also allows reducing the associated cost. Bochi et al. (2008) did not find alterations in the evaluation of the judges for the texture and succulence of burgers produced with increasing inclusion levels of pulp from silver catfish filleting residues. However, the formulation with greater inclusion of pulp reached a lower level of acceptability.

Regarding the burger purchase intention test, Figure 1 shows that the formulation with $30 \%$ pulp presented the highest index (50\%) in comparison to the formulations with $0 \%$ pulp $(29.6 \%)$ or $15 \%$ pulp $(35.1 \%)$.

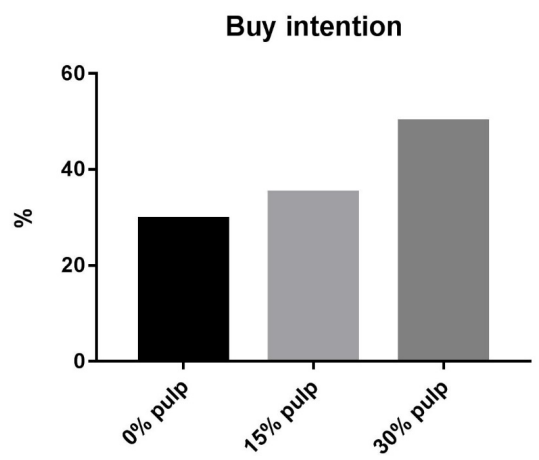

Figure 1. Intention to purchase burgers based on fillet and grumatã pulp.

These data demonstrate the potential of grumatã in the fish processing industry and how its meat can be fully utilized to produce food formulations of high nutritional value and high commercial acceptance. Our data also corroborate the diversification of fish products available for the consumer population, besides valuing the species in question.

\section{Conclusion}

Grumatã meat can be harvested in an integral manner (fillet and pulp) to produce burger formulations of high nutritional value and satisfactory consumer acceptance. In addition, the formulation with greater inclusion of pulp resulted in a higher percentage of purchase intention, which can stimulate the processing and commercial valorization of this species.

\section{Acknowledgements}

To the National Council for Scientific and Technological Development (CNPq-Brasil) for the financial support (Process Number 404282/2016-4). To Mr. Ângelo M. B. Neto (Granja Pai Passo) for the transfer of the place for fish collection.

\section{References}

Association of Official Analytical Chemists - AOAC. (1995). Official methods of analysis of AOAC International (12th ed.). Washington: AOAC.

Basso, L., Ferreira, M. W., \& Silva, A. R. (2011). Efeito do peso ao abate nos rendimentos dos processamentos do pacu (Piaractus mesopotamicus). Arquivo Brasileiro de Medicina Veterinária e Zootecnia, 63(5), 1260-1262. http://dx.doi.org/10.1590/S010209352011000500033

Bernardino Filho, R., de Queiroga, A. X. M., Gomes, Q. O., Pereira, B. B. M., \& Maracajá, P. B. (2014). Elaboração de hambúrguer formulado com filé de peixe tucunaré (Cichla spp.). Revista Verde de Agroecologia e Desenvolvimento Sustentável, 9(3), 75-80.

Bligh, E. G., \& Dyer, W. J. (1959). A rapid method of total lipid extraction and purification. Canadian Journal of Biochemistry and Physiology, 37(8), 911-917. PMid:13671378. http://dx.doi.org/10.1139/059-099

Bochi, V. C., Weber, J., Ribeiro, C. P., Victório, A. M., \& Emanuelli, T. (2008). Fishburgers with silver catfish (Rhamdia quelen) filleting residue. Bioresource Technology, 99(18), 8844-8849. PMid:18562198. http://dx.doi.org/10.1016/j.biortech.2008.04.075 
Bombardelli, R. A., Syperreck, M. A., \& Sanches, E. A. (2005). Situação atual e perspectivas para o consumo, processamento e agregação de valor ao pescado. Arquivos de Ciências Veterinárias e Zoologia da UNIPAR, 8(2), 181-195. http://dx.doi.org/10.25110/arqvet.v8i2.2005.57

Bordignon, A. C., de Souza, B. E., Bohnenberger, L., Hilbig, C. C., Feiden, A., \& Boscolo, W. R. (2010). Elaboração de croquete de tilápia do Nilo (Oreochromis niloticus) a partir de CMS e aparas do corte em "V" do filé e sua avaliação físico-química, microbiológica e sensorial. Acta Scientiarum Animal Science, 32(1), 109-116.

Brasil. Ministério da Agricultura, Pecuária e Abastecimento. (2000, julho 31). Regulamentos técnicos de identidade e qualidade de almôndega, fiambre, hambúrguer, quibe, presunto cozido e de presunto (Instrução normativa $n^{\circ} 20$, de 31 de julho de 2000). Diário Oficial da União, Brasília.

Brasil. Ministério da Saúde. (2001, janeiro 10). Dispõe sobre os padrões microbiológicos para alimentos; revoga a Portaria SVS/MS 451, de 19 de dezembro de 1997 (Resolução no 12, de 2 de janeiro de 2001). Diário Oficial da União, Brasília.

Brasil. Ministério da Agricultura, Pecuária e Abastecimento. (2003, setembro 18). Dispõe sobre os métodos analíticos oficiais para análises microbiológicas para controle de produtos de origem animal e água (Instrução normativa n 62, de 26 de agosto de 2003) Diário Oficial da União, Brasília.

Brasil. Ministério da Pesca e Aquicultura. (2012). Boletim estatístico da pesca e aquicultura Brasil 2010. Brasília: MPA. Recuperado em 11 de fevereiro de 2019, de http://www.mpa.gov.br

Dutcosky, S. D. (2011). Análise sensorial de alimentos (3. ed.). Curitiba: Champagnat.

Fernandes, D. V. G. S., Castro, V. S., Cunha Neto, A., \& Figueiredo, E. E. S. (2018). Salmonella spp. in the fish production chain: A review. Ciência Rural, 48(8), 1-11. http://dx.doi.org/10.1590/0103-8478cr20180141

Finkler, J. K., Boscolo, W. R., dos Reis, E. S., Veit, J. C., Feiden, A., \& Moore, O. Q. (2010, Agosto-Setembro). Elaboração de hambúrguer de peixe (mandi-pintado Pimelodus britskii). In Anais do II Simpósio Nacional de Engenharia de Pesca e XII Semana Acadêmica de Engenharia de Pesca, Toledo, Paraná. Recuperado em 11 de fevereiro de 2019, de http://cacphp.unioeste.br/eventos/engenhariapesca/eventos/II_SINPESCA/Engenharia_de_Pesca/arquivo22.pdf

Fonseca, F. A. L., Ituassú, D. R., Cavero, B. A. S., \& Bordinhon, A. M. (2010). Cultivo de curimatã (Prochilodus spp). In B. Baldisserotto \& L. C. Gomes (Eds.), Espécies nativas para piscicultura no Brasil (pp. 57-71). Santa Maria: Editora UFSM.

Gomiero, J. S. G., Ribeiro, P. A. D., Ferreira, M. W., \& Logato, P. V. R. (2003). Rendimento de carcaça de peixe matrinxã (Brycon cephalus) nos diferentes cortes de cabeça. Ciência e Agrotecnologia, 27(1), 211-216. http://dx.doi.org/10.1590/S141370542003000100027

Machado, M. R., \& Foresti, F. (2009). Rendimento e composição química do filé de Prochilodus lineatus do Rio Mogi Guaçu, Brasil. Archivos de Zootecnia, 58(224), 663-670. http://dx.doi.org/10.21071/az.v58i224.5056

Maciel, E. S., Galvão, J. A., Arruda, L. F., Savay-da-Silva, L. K., Angelini, M. F. C., \& Oetterer, M. (2012). Recomendações técnicas para processamento da tilápia (1. ed.). Teresina: Embrapa Meio-Norte.

Mello, S. C. R. P., Freitas, M. Q., São Clemente, S. C., Franco, R. M., Nogueira, E. B., \& Freitas, D. D. G. C. (2012). Development and bacteriological, chemical and sensory characterization of fishburgers made of Tilapia minced meat and surimi. Arquivo Brasileiro de Medicina Veterinária e Zootecnia, 64(5), 1389-1397. http://dx.doi.org/10.1590/S0102-09352012000500041

Moro, G. V., Rezende, F. P., Alves, A. L., Hashimoto, D. T., Varela, E. S., \& Torati, L. S. (2013). Espécies de peixe para piscicultura. In A. P. O. Rodrigues, A. F. Lima, A. L. Alves, D. K. Rosa, L. S. Torati \& V. R. V. Santos (Eds.), Piscicultura de água doce: Multiplicando conhecimentos (pp. 31-49). Brasília: Embrapa.

Munhoz, C. L., \& Camponazo, R. J. (2018). Elaboração de fishburguer do peixe armau (Pterodoras granulosus). Revista Inova Ciência e Tecnologia, 4(1), 20-24.

Oliveira, P. R., Jesus, R. S., Batista, G. M., \& Lessi, E. (2014). Avaliação sensorial, físico-química e microbiológica do pirarucu (Arapaima gigas, Schinz 1822) durante estocagem em gelo. Brazilian Journal of Food Technology, 17(1), 67-74. http://dx.doi.org/10.1590/bjft.2014.010

Pinheiro, L. M. S., Martins, R. T., Pinheiro, L. A. S., \& Pinheiro, L. E. L. (2006). Rendimento industrial de filetagem da tilápia tailandesa (Oreochromis spp.). Arquivo Brasileiro de Medicina Veterinária e Zootecnia, 58(2), 257-262. http://dx.doi.org/10.1590/S010209352006000200015

Pires, D. R., Morais, A. C. N., Costa, J. F., Góes, L. C. D. S. A., \& Oliveira, G. M. (2014). Aproveitamento do resíduo comestível do pescado: Aplicação e viabilidade. Revista Verde de Agroecologia e Desenvolvimento Sustentável, 9(5), 34-46.

Pretto, A., Camargo, A. C. S., Centenaro, G. S., Tamajusuku, A. S. K., Teixeira, U. T., \& Rodrigues, A. T. (2017). Características sensoriais e bromatológicas da carne de Prochilodus lineatus após depuração. Caderno de Ciências Agrárias, 9(3), 25-29.

Pretto, A., Camargo, A. C. S., Denardin, C. C., Ribeiro, V. B., \& Kuroda, C. N. (2019). Análise bromatológica, microbiológica e sensorial de croquetes de carne de Prochilodus lineatus. Agrarian, 12(44), 272-278. http://dx.doi.org/10.30612/agrarian.v12i44.7241

Reidel, A., Oliveira, L. G., Piana, P. A., Lemainski, D., Bombardelli, R. A., \& Boscolo, W. R. (2004). Avaliação de rendimento e características morfométricas curimbatá Prochilodus lineatus (Valenciennes, 1836), e do piavuçu Leporinus macrocephalus (Garavello \& Britski, 1988) machos e fêmeas. Revista Varia Scientia, 4(8), 71-78. 